In the near future, a number of these will be tentatively adopted by votes of the Committee. It is recommended that after such adoption they be referred to the Council and upon the approval of that body that they be printed in ThE Journal of the American Pharmaceutical Association.

In addition to the above list of topics the following items have been accepted by referees and their reports are anticipated in the near future:

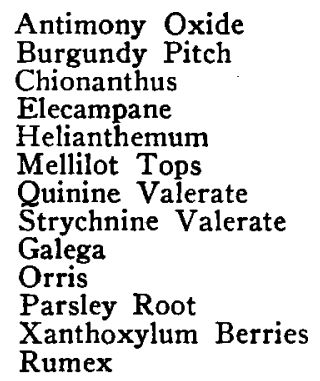

Antimony Sulphide
Caramel
Corydalis
Garlic
Hydrangea
Potassium Formate
Sodium Formate
Yeast, Compressed
Nepeta
Pimpinella Root
White Sandal Wood
Zedoary
Thyme

It is further recommended that as monographs for these articles are reported upon and tentatively adopted by the Committee, after discussion, that they likewise be reported to the Council for approval and publication. The object of this recommendation is to avoid unnecessary delay in the completion of our work and in the publication of the National Formulary.

As it is contemplated to include in the National Formulary Revision a number of formulas and drugs dismissed in the U. S. P. Revision, it will likewise be necessary either for this Committee or the Committee on National Formulary to give some attention to the standards for these drugs before they are admitted into the revised National Formulary, and such approved monographs should be reported as part of the work of this Committee and printed in the Journal

Respectfully submitted,

George M. Beringer, Chairman.
W. A. PuCKNER,
M. I. WILBERT,
Otto Raubenheimer,
H. H. Rusby,
L. D. HAVEN Hill,

J. А. Косн,

B. L. Murray,

Frank R. Eldred,

Chas. E. Vanderkleed,

HENRY KRAEMER.

\title{
REPORT OF THE COMMITTEE ON DRUG REFORM.
}

\section{E. SAYRE, CHAIRMAN.}

It will be seen, from former reports of this committee, that its efforts have been directed mainly to the cause of standardization, which term, in its broadest application touches acutely not only pharmacists and physicians but all who assume any responsibility in the practice of making, and dispensing, of medicine. Your chairman was honored by an invitation to speak on the work of this committee at the last meeting of the Kansas Medical Association. He said to the members of this association, what will bear frequent repetition: "If there are 
any avenues left open for the exploitation of sub-standard material there are those ever ready to enter them and to supply this material at all prices and in any quantity. It is unnecessary to repeat that the reputable houses are too up right and honorable to stoop to the practice of ever carelessly standardizing their products or that they would yield to the temptation of supplying two grades-one for localities and places not frequented by official inspectors and the other for other localities frequented by these. It is also needless to repeat that reputable physicians in every possible way at their command secure for themselves remedial agents which would creditably pass inspection and meet the requirements of the standard. Nevertheless, the theory is tenable: any loophole, however small, for the introduction of inferior articles, furnishes an incentive for an evasion of the law. Such incentive will invite those, always ready, to take advantage of it. Experience has shown this to be true."

During the past year an effort has been made to further the work outlined in former reports, and while nothing startling has been accomplished, the attainment of one result is a source of some encouragement. Working in connection with the Legislative Committee of the Kansas Pharmaceutical Association, reformative legislation has been secured in that state. This was bitterly opposed by certain members of the medical fraternity who misconstrued its purpose, but in spite of their antagonism, a broader application of the food and drugs law was secured. The law enacted requires that all who dispense drugs, whether from private stock of physicians, or from other supply stocks, shall be subject to the same inspection as the druggist. In other words: Drugs and medicines now dispensed by physicians or by any others from private stocks shall be subject to inspection as provided in the Kansas Food and Drugs Law, and such drugs and medicines shall comply with said law. In this respect the law previously enacted (or provision for its administration) was weak and inefficient. In order to secure this little bit of legislation some missionary work was necessary among physicians. In this work we desire to acknowledge the help of those physicians who believed that every dispenser of medicine should be held responsible for those drugs and chemicals dispensed by him.

We desire also to acknowledge the help of the Legislative Committee above referred to, and that of the president of the Association, Mr. C. C. Reed. Without such combined efforts and efficient aid the proposed legislation would have been defeated. The future usefulness-greater usefulness-of this committee on Drug Reform-seems to indicate, from past experience, that a close articulation between it and all of the various national and state legislative committees, is not only essential but necessary. To accomplish this satisfactorily would require perhaps some slight expense.

This report would be incomplete did it not refer to two well-marked sources of opposition to drug reform. This was made evident when, two sections of the bill, above referred to were considered. One of these sections contained a provision for the better regulation of the itinerant vender of patent medicines.

Chairman Eckstrand, referring to the antagonism of the patent medicine interests, says: "The committee became thoroughly convinced that the patent 
medicine influence thoroughly dominated both houses"*-hence the defeat of this section. Another section of the bill provided that: Physicians who furnished medicines from private stock, should, except in cases of emergency, write and file a prescription for the same. Said prescription should be subject to inspection by proper authority. Chairman Eckstrand reports that this section was defeated by the active interest of a large manufacturing house "that made malicious, unwarranted and yet plausible misstatements as to the intent and purpose of the bill."

The future work of this committee if continued on the lines indicated by this and previous reports; if the work be extended into every state, it would doubtless yield results worthy of the approval of this Association. There are many other lines calling for activity. One especially which relates to the nostrum and fake remedy traffic. This is alarmingly on the increase. It is irritating beyond measure and of course militating against pharmacy. The professional pharmacist is constantly striving against these so-called remedies and yet he is seemingly forced by circumstances to be their distributing agent. An act has recently been passed in Kansas for the protection of lower animals, as it were. The act relates to the regulation of the sale of medicines and nostrums for the treatment of diseases of stock. It includes stock food tonics, condition powders, proprietary medicines, etc. Each ingredient, whether it be active or a diluent is required to be registered. Should we not be equally careful for the protection of higher (human) animals? Both medicine and pharmacy should take hold of this subject with courageous hands and by degrees control this traffic-it would be an important extension and broadening of the work of standardization which this committee will probably always keep in the foreground.

It is gratifying that our Association is contemplating a scheme for the establishment of a laboratory to determine, among other things, whether it is possible to draw a distinct line of demarcation between legitimate and illegitimate remedies. $\dagger$ Such a laboratory and such work would do much to advance the interests of the pharmaceutical vocation, and would doubtless yield tangible results in the direction of drug reform.

NoTE-Unfortunately this hastily prepared report could not be submitted to other members of the committee for their approval in time for the annual meeting. The chairman wishes to express his thanks for their valuable advice and assistance during the year.
Albert Schneider, E. N. Gathercoal, L. E. SAYre,

Committee.

\footnotetext{
* Chairman Eckstrand's report is published in pamphlet form.

† See August, 1912, issue of the Journal of THE A. Pr. A.
} 